Article

\title{
Amino Acid Composition, Antioxidant, and Cytoprotective Effect of Blue Mussel (Mytilus edulis) Hydrolysate through the Inhibition of Caspase-3 Activation in Oxidative Stress-Mediated Endothelial Cell Injury
}

\author{
Yunok Oh ${ }^{1,+}$, Chang-Bum Ahn ${ }^{2,+}$, Ki-Ho Nam ${ }^{3}$, Yeon-Kye Kim ${ }^{3}$, Na Young Yoon ${ }^{3}$ \\ and Jae-Young Je ${ }^{1, *}$ \\ 1 Department of Marine-Bio Convergence Science, Pukyong National University, Busan 48547, Korea; \\ si565@daum.net \\ 2 Division of Food and Nutrition, Chonnam National University, Gwangju 61186, Korea; a321@jnu.ac.kr \\ 3 Food Safety and Processing Research Division, National Fisheries Research \& Development Institute, \\ Busan 4608, Korea; dennis011@korea.kr (K.-H.N.); yeonkyekim@korea.kr (Y.-K.K.); \\ dbssud@korea.kr (N.Y.Y.) \\ * Correspondence: jjy1915@pknu.ac.kr; Tel.: +82-51-629-6871; Fax: +82-51-629-6865 \\ + These authors equally contributed to this work.
}

Received: 30 January 2019; Accepted: 21 February 2019; Published: 25 February 2019

\begin{abstract}
Enhanced oxidative stress plays a central role in promoting endothelial dysfunction, leading to the development of atherosclerosis. In this study, we investigated the protective effects of the hydrolysates derived from blue mussel (Mytilus edulis) against $\mathrm{H}_{2} \mathrm{O}_{2}$-mediated oxidative injury in human umbilical vein endothelial cells (HUVECs). The blue mussel hydrolysates were prepared by enzymatic hydrolysis with eight proteases, and blue mussel- $\alpha$-chymotrypsin hydrolysate (BMCH) showed the highest antioxidant activities in DPPH radical scavenging, $\mathrm{ABTS}^{+}$radical scavenging, and ORAC value compared to those of the other hydrolysates. $\mathrm{BMCH}$ also inhibited $\mathrm{Cu}^{2+}$-mediated low density lipoprotein (LDL) oxidation. Treatment of $\mathrm{H}_{2} \mathrm{O}_{2}$ resulted in the decreased HUVEC viability whereas pre-treatment with $\mathrm{BMCH}$ increased HUVEC viability and reduced reactive oxygen species (ROS) generation. BMCH pre-treatment increased cellular antioxidant capacities, including levels of glutathione (GSH), superoxide dismutase (SOD), catalase (CAT), and glutathione peroxidase (GPx) against $\mathrm{H}_{2} \mathrm{O}_{2}$-mediated oxidative stress in HUVECs. Flow cytometry and western blot analysis revealed that $\mathrm{BMCH}$ pre-treatment significantly reduced $\mathrm{H}_{2} \mathrm{O}_{2}$-mediated HUVEC apoptosis through inhibition of caspase-3 activation. Real-time-qPCR analysis showed that BMCH down-regulated expression of p53 and caspase- 3 genes, as well as decreased the bax/bcl-2 ratio. Taken together, these results indicate that $\mathrm{BMCH}$ may be useful as functional food ingredients for protecting endothelial dysfunction or related disease.
\end{abstract}

Keywords: blue mussel; bioactive peptide; endothelial dysfunction; oxidative stress; caspase-3 activation

\section{Introduction}

Endothelial dysfunction is an early event in the development of atherosclerosis, the major cause of cardiovascular diseases, which is the leading cause of death worldwide [1-3]. Atherosclerosis occurs with subsequent endothelial damage caused by a number of risk factors, such as dyslipidemias, hypertension, diabetes mellitus, smoking, and obesity [4,5]. These common risk factors for 
atherosclerosis are associated with an increased production of reactive oxygen species (ROS) [6,7]. ROS can induce damage in endothelium through direct oxidation of cellular protein, lipid, DNA, and small cellular molecules [8]. In addition, oxidative stress by ROS can also activate cell signaling pathways related to atherosclerosis, which subsequently controls the regulation of gene expression [9]. When the endothelium becomes damaged, atherosclerosis plaques filled with cellular debris and form cells begin to accumulate in artery walls, thus resulting in a narrowing of arteries that can subsequently cause a blockage or stroke $[10,11]$. Usually, there are no signs and symptoms until severe narrowing or total blockage of arteries. Thus, pre-treatment with well-established antioxidants is a good strategy for the preventing of atherosclerosis before incidence of severe atherosclerosis.

Over several decades, marine natural products have been vastly explored due to their excellent antioxidant activity in nutrients, pharmaceuticals, and cosmeceutical industries [12-14]. One of the well-characterized methods for preparation of antioxidant peptides from food proteins is enzymatic hydrolysis [15-17]. Blue mussel (M. edulis) is widely cultured in Korea and used as a foodstuff. Because of rich protein content in blue mussels, antioxidant hydrolysates and peptides from blue mussels by enzymatic hydrolysis were reported by different research groups [18,19]. However, no information is available with reference to an anti-atherosclerotic effect of blue mussel proteins or its hydrolysates against oxidative stress-mediated endothelial dysfunction. In the present study, we prepared eight kinds of blue mussel hydrolysates (BMHs) in order to find suitable anti-atherosclerotic hydrolysates and evaluated a molecular mechanism underlying anti-atherosclerotic effect in oxidative stress-mediated endothelial cell injury. In addition, several marine-derived compounds that are capable of HUVEC protection against oxidative stress have been reported [20-22]. Here, we investigated the protective effect of $\mathrm{BMH}$ on $\mathrm{H}_{2} \mathrm{O}_{2}$-mediated HUVEC injury. Our finding demonstrated that $\mathrm{BMH}$ has a protective effect against $\mathrm{H}_{2} \mathrm{O}_{2}$-induced HUVEC apoptosis associated with the inhibition of an apoptosis related pathway.

\section{Results}

\subsection{Antioxidant and Inhibitory Effect of BMHs on LDL Oxidation}

Oxidative stress can promote endothelial dysfunction, which is an initial step of the pathogenesis of atherosclerosis [23]. Prior to evaluate cytoprotective effect of BMHs against oxidative stress-mediated endothelial cell injury, antioxidant activity of BMHs was determined using DPPH, ABTS ${ }^{+}$, and ORAC assays in order to select potential cytoprotective hydrolysate. As shown in Figure 1, papain hydrolysate showed the highest $\mathrm{DPPH}$ radical scavenging activity $\left(\mathrm{IC}_{50}\right.$ of $0.33 \pm 0.01 \mathrm{mg} / \mathrm{mL}$ ), followed by $\alpha$-chymotrypsin hydrolysate ( $\mathrm{IC}_{50}$ of $0.35 \pm 0.03 \mathrm{mg} / \mathrm{mL}$ ), with no significant difference. Otherwise, $\alpha$-chymotrypsin hydrolysate showed the highest $\mathrm{ABTS}^{+}$radical scavenging $(117 \pm 3.5 \mu \mathrm{M} \mathrm{TE} / \mathrm{mg}$ sample) and ORAC (199.62 $\pm 1.42 \mu \mathrm{M}$ TE/mg sample). Thus, we selected BMH by $\alpha$-chymotrypsin $(\mathrm{BMCH})$ for further experiments.

LDL is sensitive against ROS and oxidized LDL can promote atherosclerosis, perhaps serving as evidence of atherosclerosis in the early stage [24]. Thus, we evaluated the inhibitory effect of $\mathrm{BMCH}$ against $\mathrm{Cu}^{2+}$-mediated LDL oxidation by measuring TBARS that were expressed as MDA concentration. Incubation with $\mathrm{Cu}^{2+}$ (control) resulted in the significant increase of TBARS; however, this value was decreased by $22.03 \pm 1.24$ and $15.56 \pm 0.65 \mu \mathrm{M}$ MDA in the presence of BMCH of 0.5 and $1.0 \mathrm{mg} / \mathrm{mL}$. This result indicated that BMCH could inhibit LDL oxidation. 
A

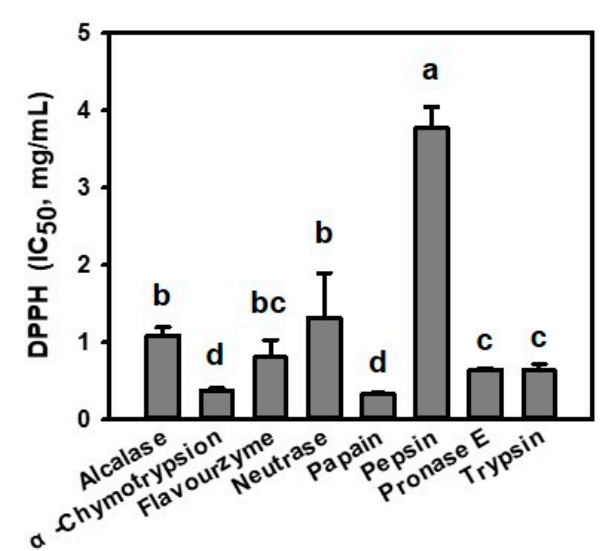

C

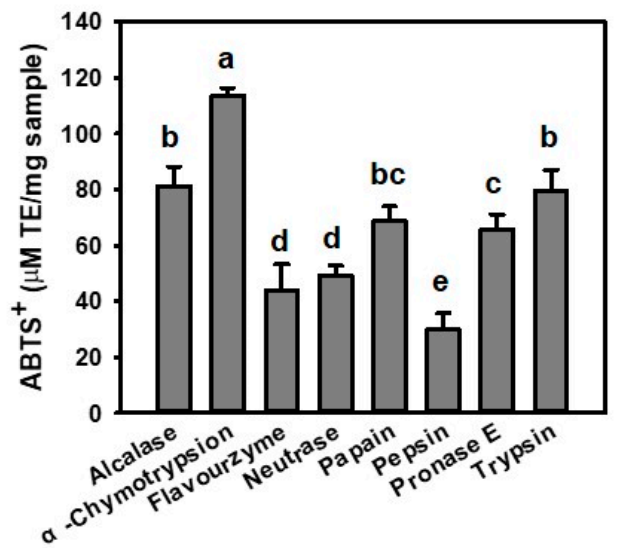

B

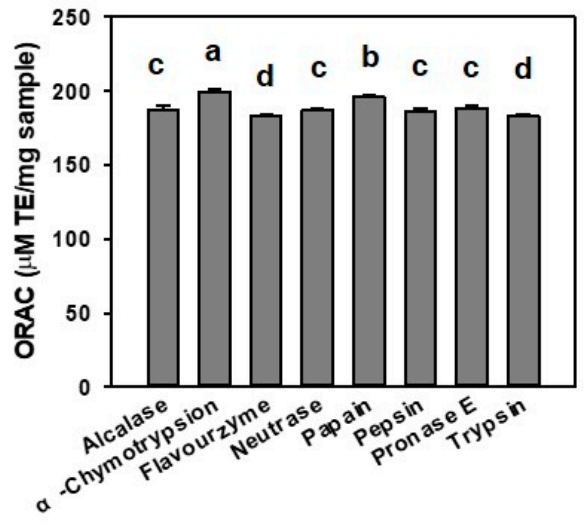

D

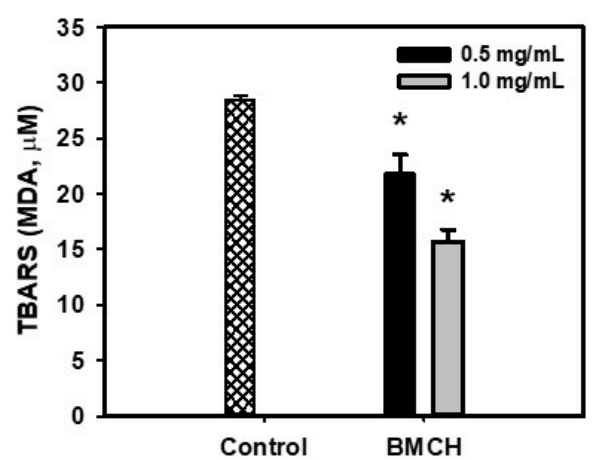

Figure 1. Antioxidant abilities of blue mussel hydrolysates with various proteolytic enzymes determined by (A) DPPH scavenging assay, (B) ORAC assay, (C) ABTS ${ }^{+}$radical assay, and (D) TBARS assay. ${ }^{\mathrm{a}-\mathrm{d}}$ Different letters on the bar charts indicated significant differences $(p<0.05) .{ }^{*} p<0.05$ vs. control.

\subsection{The Protective Effect of BMCH against $\mathrm{H}_{2} \mathrm{O}_{2}$-Induced Cytotoxicity in HUVEC}

ROS-mediated vascular endothelial cell damage is strongly related to developing cardiovascular diseases including atherosclerosis [25]. Thus, we established the $\mathrm{H}_{2} \mathrm{O}_{2}$-induced HUVEC injury model and explored whether BMCH could mitigate $\mathrm{H}_{2} \mathrm{O}_{2}$-induced HUVEC injury. The result of cytotoxic assay revealed that $\mathrm{BMCH}$ treatment showed no cytotoxic effect up to $0.5 \mathrm{mg} / \mathrm{mL}$; however, $\mathrm{BMCH}$ showed around $20 \%$ cytotoxic effect on HUVECs at $1.0 \mathrm{mg} / \mathrm{mL}$ (Figure 2A). Figure 2B shows the protective effect of $\mathrm{BMCH}$ against $\mathrm{H}_{2} \mathrm{O}_{2}$-induced HUVEC injury. A $600 \mu \mathrm{M} \mathrm{H}_{2} \mathrm{O}_{2}$ treatment significantly decreased HUVEC viability $(64.76 \pm 0.08 \%)$; however, pretreatment of $\mathrm{BMCH}$ increased HUVEC viability up to $85.35 \pm 3.42 \%$ at $0.5 \mathrm{mg} / \mathrm{mL}$, indicating $\mathrm{BMCH}$ ameliorated $\mathrm{H}_{2} \mathrm{O}_{2}$-induced HUVEC injury.

To further confirm the in vitro protective effect of $\mathrm{BMCH}$ in HUVEC injury, live/dead cells observation was carried out using the calcein AM/PI double staining. As shown in Figure 2C, the control (without treatments) clearly showed a strong green fluorescence, indicating a uniformly confluent layer of viable cells. Next, the cells treated with $\mathrm{H}_{2} \mathrm{O}_{2}$ alone displayed a reduced number of viable cells (green) and an increased number of dead cells (red). The cells with pretreatment of BMCH before $\mathrm{H}_{2} \mathrm{O}_{2}$ exposure displayed a reduced number of dead cells with reduced red fluorescence intensity compared to $\mathrm{H}_{2} \mathrm{O}_{2}$ alone treatment, indicating the cytoprotective effect of $\mathrm{BMCH}$ against $\mathrm{H}_{2} \mathrm{O}_{2}$-induced HUVEC injury. 
A

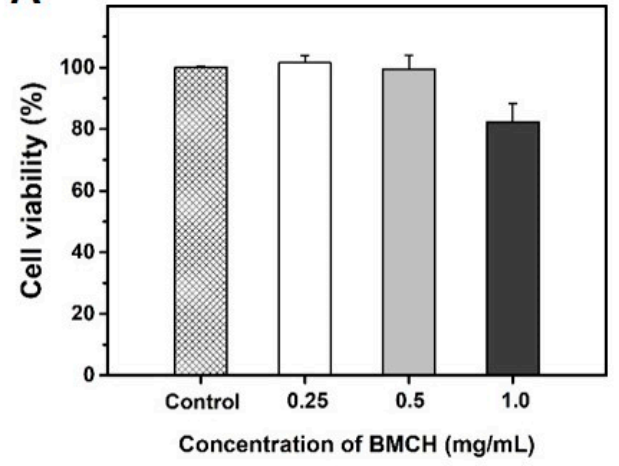

B

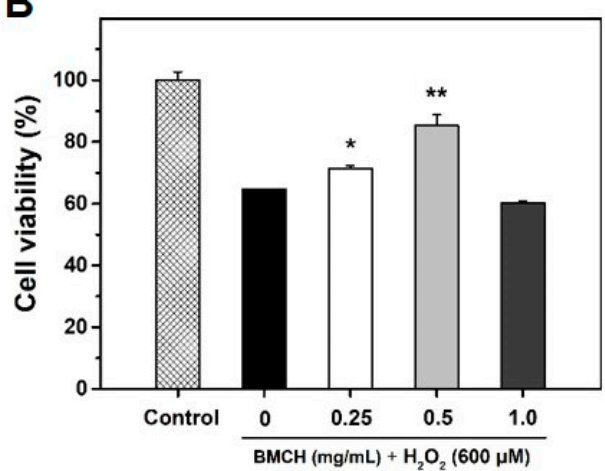

$\mathrm{BMCH}+\mathrm{H}_{2} \mathrm{O}_{2}(600 \mu \mathrm{M})$

C
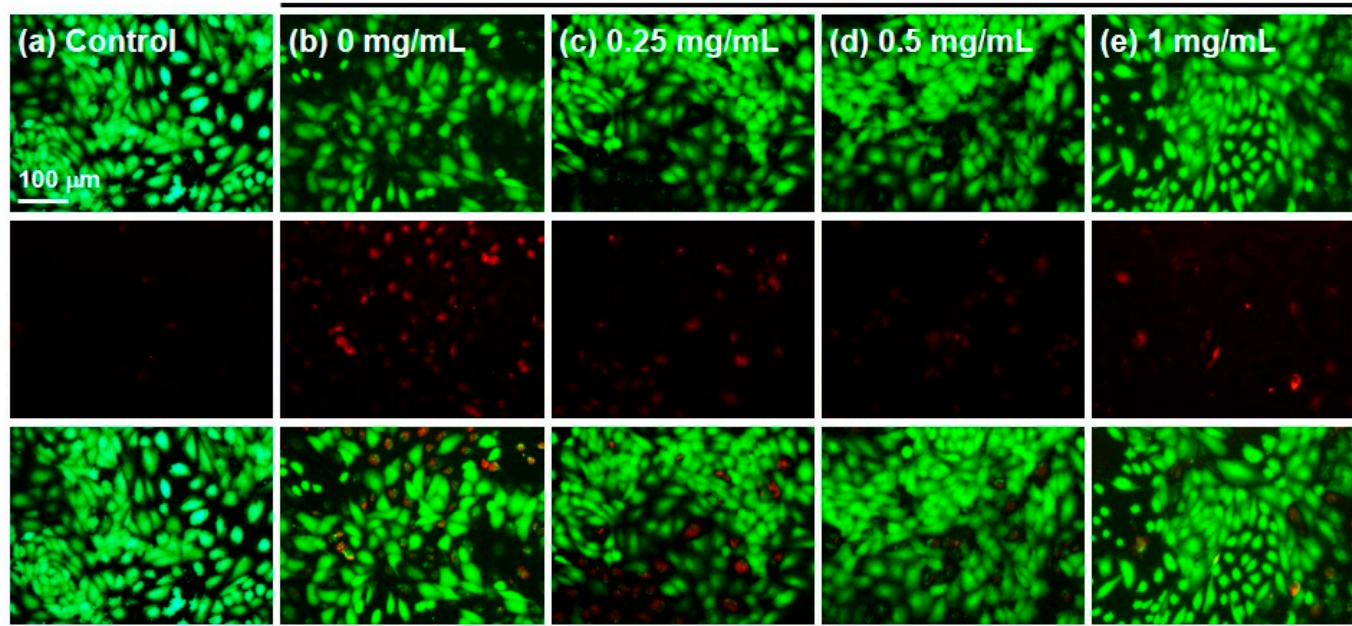

Figure 2. Effect of BMCH on oxidative stress-mediated HUVEC injury. (A) Cell viability and (B) the protective effect of $\mathrm{BMCH}$ in $\mathrm{H}_{2} \mathrm{O}_{2}$-mediated HUVEC injury, as determined by MTT assay, and (C) live-dead cell assay by calcein-AM/PI double staining. Cells were pretreated with BMCH for 30 min followed by exposure of $\mathrm{H}_{2} \mathrm{O}_{2}(600 \mu \mathrm{M})$ and incubation for $24 \mathrm{~h} .{ }^{*} p<0.05$ and ${ }^{* *} p<0.01$ vs. $\mathrm{H}_{2} \mathrm{O}_{2}$ only treatment.

\subsection{BMCH Treatment Inhibits ROS Generation in $\mathrm{H}_{2} \mathrm{O}_{2}$-Induced HUVEC Injury}

Because ROS is a key regulator in vascular diseases, the inhibitory effect of $\mathrm{BMCH}$ on intracellular ROS generation was investigated using DCFH-DA assay. As shown in Figure $3 \mathrm{~A}, \mathrm{H}_{2} \mathrm{O}_{2}$ alone treatment showed bright DCF green fluorescence, indicating the increase of intracellular ROS generation, whereas the control showed no DCF green fluorescence, and the fluorescence intensity of DCF in the HUVECs treated with $\mathrm{BMCH}$ was decreased compared to that of $\mathrm{H}_{2} \mathrm{O}_{2}$ alone treatment. This result indicated that $\mathrm{BMCH}$ effectively quenched intracellular ROS in $\mathrm{H}_{2} \mathrm{O}_{2}$-mediated HUVEC injury. We further confirmed by quantification using microplate reader that $\mathrm{BMCH}$ treatment decreased the intracellular ROS generation in $\mathrm{H}_{2} \mathrm{O}_{2}$-induced HUVEC injury (Figure $3 \mathrm{~B}$ ). The results indicated that $\mathrm{BMCH}$ pretreatment can suppress the intracellular ROS generation from $\mathrm{H}_{2} \mathrm{O}_{2}$-induced HUVEC injury. 
A

$\mathrm{BMCH}+\mathrm{H}_{2} \mathrm{O}_{2}(600 \mu M)$
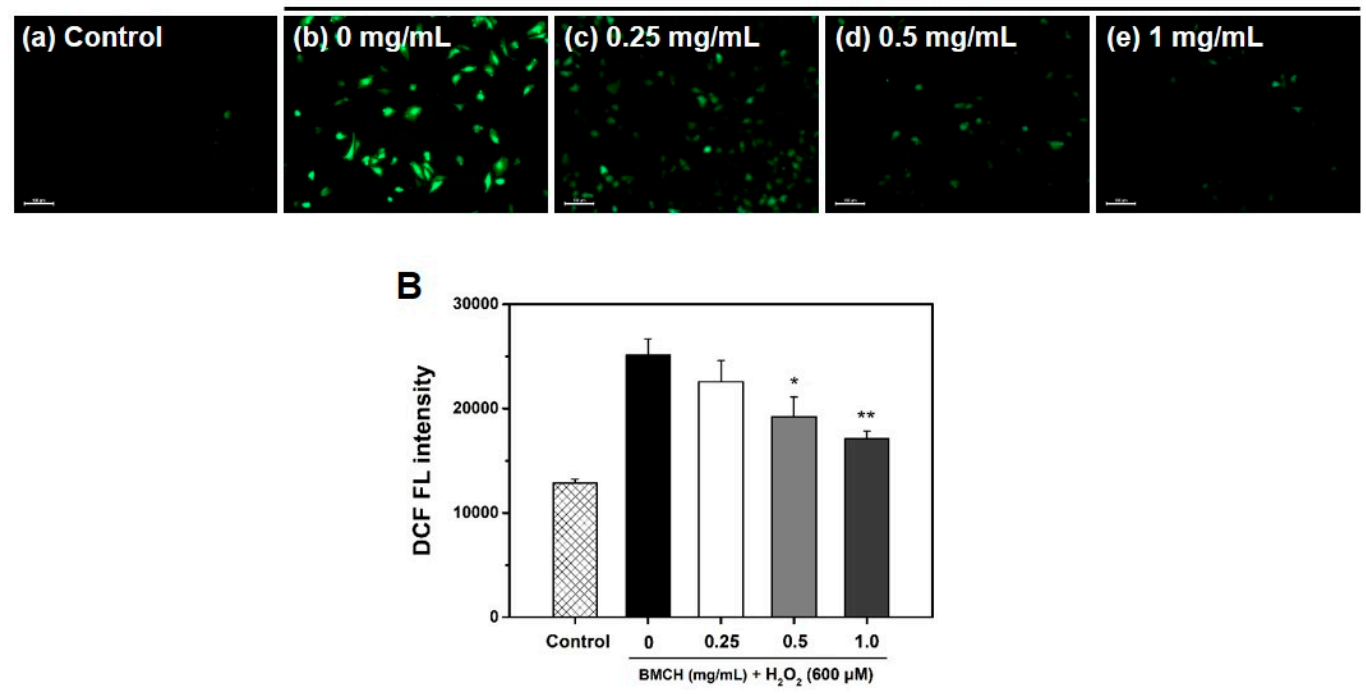

Figure 3. (A) Determination of intracellular ROS production by DCFH-DA staining under a fluorescence microscope and (B) quantitative intracellular DCF fluorescence intensity in $\mathrm{H}_{2} \mathrm{O}_{2}$-treated HUVEC. Cells were pretreated with $\mathrm{BMCH}$ for $30 \mathrm{~min}$, followed by exposure of $\mathrm{H}_{2} \mathrm{O}_{2}(600 \mu \mathrm{M})$ and incubation for 24 h. ${ }^{*} p<0.05$ and ${ }^{* *} p<0.01$ vs. $\mathrm{H}_{2} \mathrm{O}_{2}$ only treatment.

\subsection{BMCH Enhanced the Levels of Intracellular GSH and Antioxidant Enzyme Activities}

To investigate the protective mechanism of $\mathrm{BMCH}$ against $\mathrm{H}_{2} \mathrm{O}_{2}$-mediated HUVEC injury, we first investigated intracellular GSH level. GSH, a well-charaterized antioxidant, is endogeneously synthesized in all cells and plays a key role in antioxidant defense against oxidative stress [26]. As depicted in Figure 4A,B, GSH level was significantly increased by BMCH treatment under both normal and oxidative stress conditions. $\mathrm{H}_{2} \mathrm{O}_{2}$ alone treatment resulted in the decrease of $14.33 \%$ in intracellular GSH level compared the control, but reduced GSH level caused by $\mathrm{H}_{2} \mathrm{O}_{2}$ treatment was completely restored and increased by $\mathrm{BMCH}$ treatment.

Next, we determined three antioxidant enzyme activities including SOD, CAT, and GPx because these enzymes are associated with cytoprotection against oxidative stress-mediated cell injury. As shown in Figure 4C-E, significant depletions of SOD, CAT, and GPx were detected in $\mathrm{H}_{2} \mathrm{O}_{2}$ treatment compared to that in the control group. However, three antioxidant enzyme activities were significantly restored by $\mathrm{BMCH}$ pretreatment. 

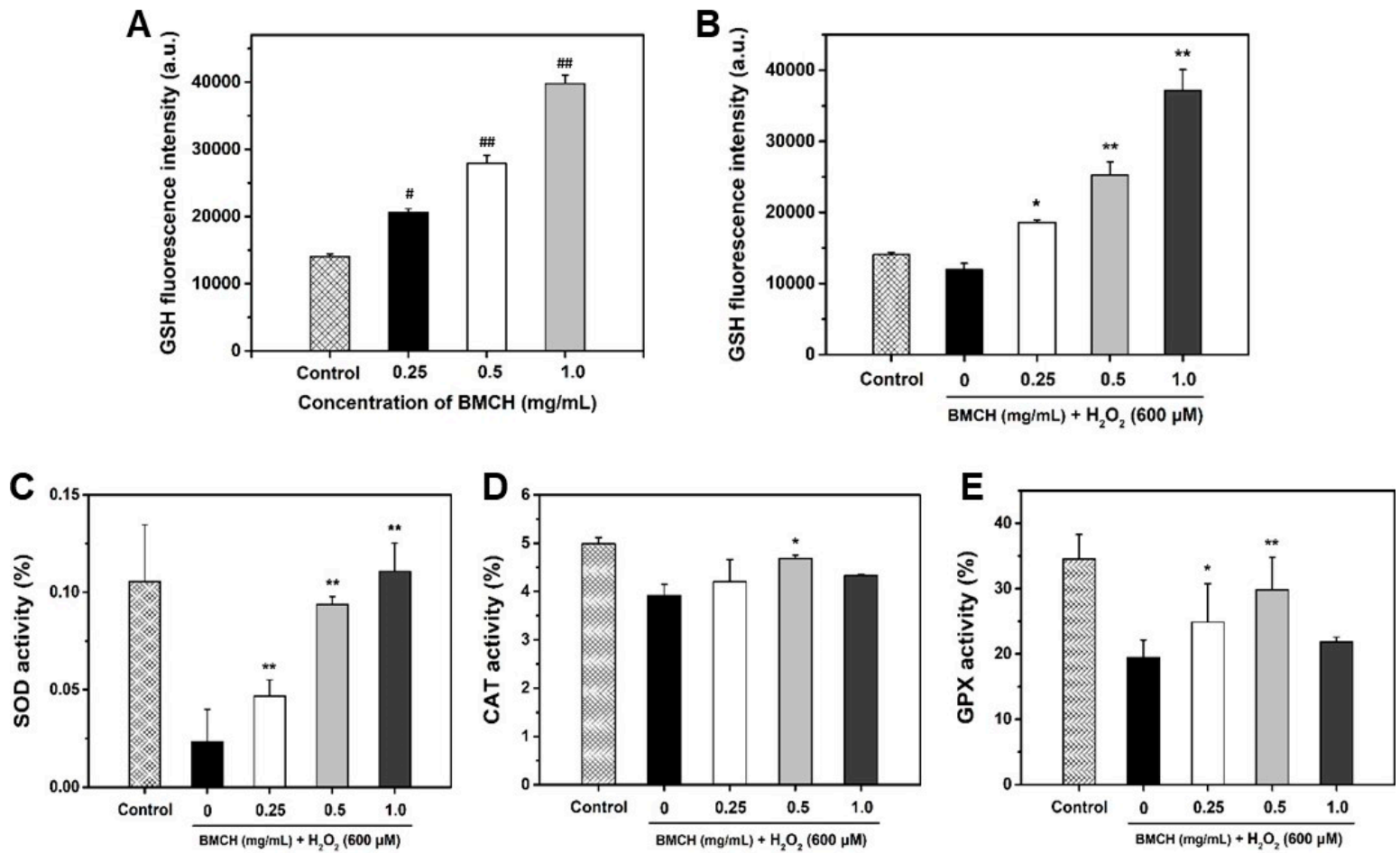

Figure 4. Quantification of intracellular GSH levels under (A) normal and (B) oxidative stress condition and determination of antioxidant enzyme levels (C) SOD, (D) CAT, and (E) GPx activities. Cells were treated with $\mathrm{BMCH}$ for $24 \mathrm{~h}$ for measurement of GSH level under normal condition. Cells were pretreated with $\mathrm{BMCH}$ for $30 \mathrm{~min}$ followed by exposure of $\mathrm{H}_{2} \mathrm{O}_{2}(600 \mu \mathrm{M})$ and incubation for $24 \mathrm{~h}$ for measurement of GSH under oxidative stress condition and antioxidant enzyme activities. Differences were considered statistical significance at ${ }^{\#} p<0.05$ and ${ }^{\# \#} p<0.01$ compared with the control, and * $p<0.05$ and ${ }^{* *} p<0.01$ compared with the cells treated with $\mathrm{H}_{2} \mathrm{O}_{2}$ only treatment.

\subsection{Prevention of Apoptosis and Necrosis by BMCH Treatment in $\mathrm{H}_{2} \mathrm{O}_{2}$-Mediated HUVEC Injury}

ROS play an important role in apoptosis induction. Thus, the anti-apoptotic effect of BMCH in oxidative stress-mediated HUVEC injury was determined using Hoechst 33342 nuclear and Annexin V-PI double staining. As shown in Figure 5A,B, injured morphologies with nuclear condensation in the $\mathrm{H}_{2} \mathrm{O}_{2}$ treatment group were observed whereas the control cells were typical HUVEC morphology without nuclear condensation. These morphological changes in $\mathrm{H}_{2} \mathrm{O}_{2}$-mediated HUVEC injury were reversed by $\mathrm{BMCH}$ treatment $(0.25$ and $0.5 \mathrm{mg} / \mathrm{mL})$.

Next, we assessed the effect of BMCH on HUVEC apoptosis and necrosis by $\mathrm{H}_{2} \mathrm{O}_{2}$ treatment using Annexin V-PI double staining (Figure 5C,D). $\mathrm{H}_{2} \mathrm{O}_{2}$ treatment for $24 \mathrm{~h}$ increased in the apoptotic $(21.41 \pm 2.67 \%)$ and necrotic cells $(13.06 \pm 0.95 \%)$ compared to the control group, indicating that $\mathrm{H}_{2} \mathrm{O}_{2}$ induced cell death in both pathways. At $0.25 \mathrm{mg} / \mathrm{mL}$ of $\mathrm{BMCH}$, necrotic cells were decreased, but apoptotic cells were slightly increased compared to that of the control group. However, total cell death was significantly decreased. At $0.5 \mathrm{mg} / \mathrm{mL}$ of $\mathrm{BMCH}$, both necrotic and apoptotic cells were significantly decreased, but treatment of $\mathrm{BMCH}$ with high concentration resulted in cell death by increasing apoptosis ; this is in agreement with cytotoxic evaluation in Figure 2. This result indicates that $\mathrm{BMCH}$ with low concentration is effective in protection against $\mathrm{H}_{2} \mathrm{O}_{2}$-induced HUVEC injury, but not high a concentration of BMCH in our model. 
$\mathrm{BMCH}+\mathrm{H}_{2} \mathrm{O}_{2}(600 \mu \mathrm{M})$

A
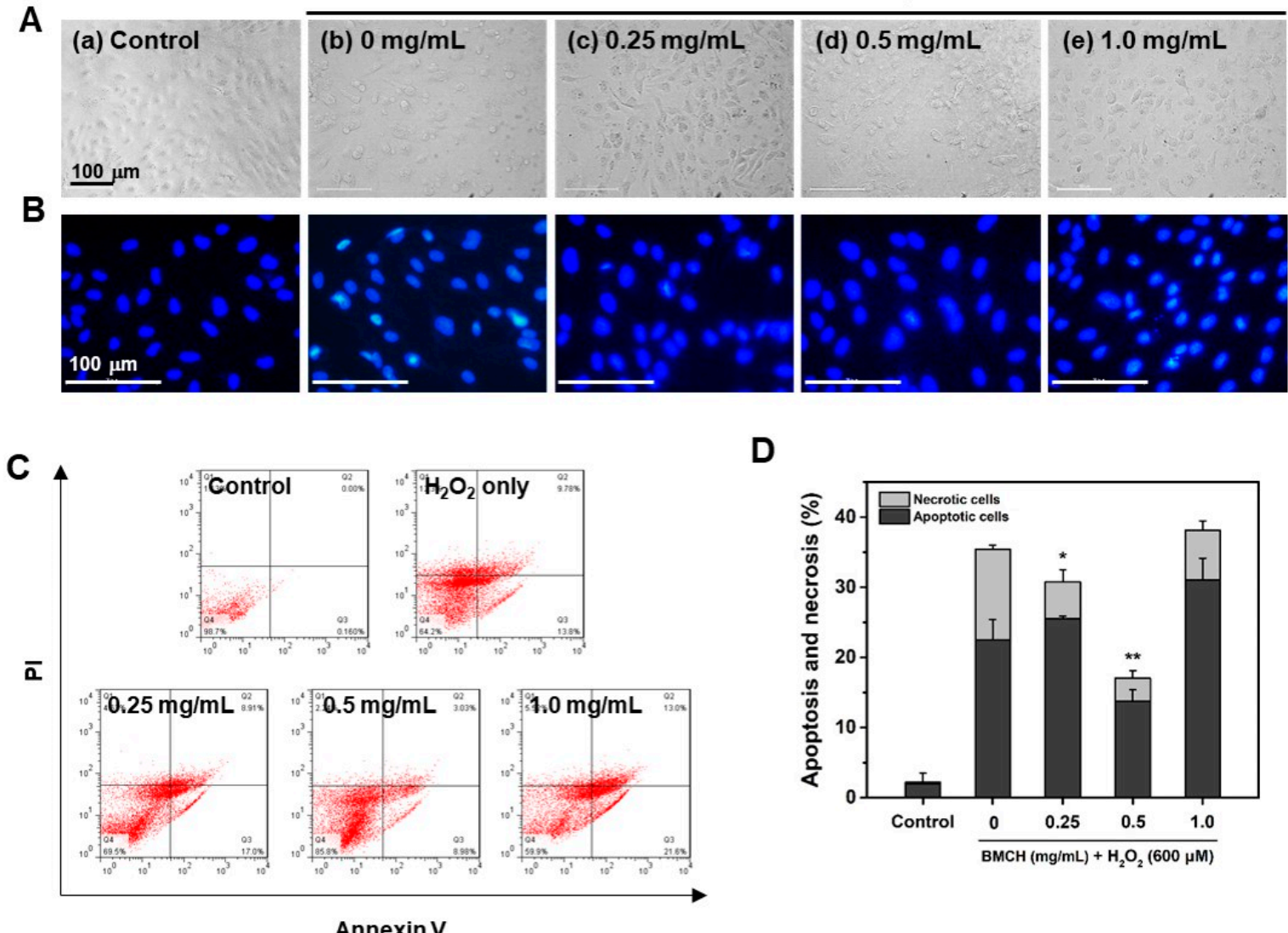

D

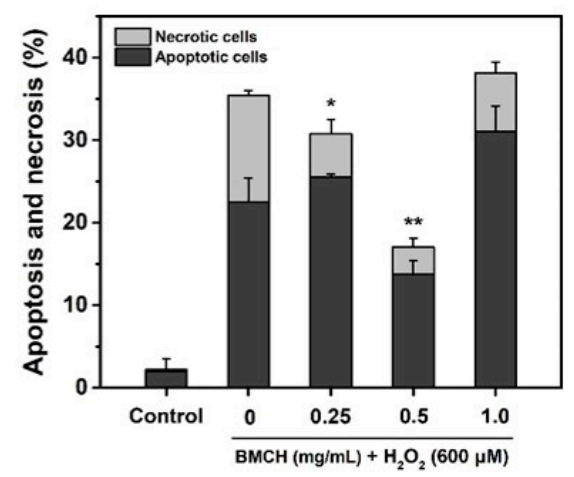

Figure 5. Effects of BMCH on apoptosis in $\mathrm{H}_{2} \mathrm{O}_{2}$-treated HUVEC injury. (A) Cellular morphology and (B) nuclear morphology by $\mathrm{H} 33342$ staining under a fluorescence microscope. (C) FACS analysis using Annexin V-FITC apoptosis kit and (D) quantification of apoptotic and necrotic cells by FACS analysis. ${ }^{*} p<0.05$ and ${ }^{* *} p<0.01$ vs. $\mathrm{H}_{2} \mathrm{O}_{2}$ only treatment.

\subsection{Modulation of Apoptosis-Related Genes by BMCH in $\mathrm{H}_{2} \mathrm{O}_{2}$-Induced HUVEC Injury}

To verify the anti-apoptotic effect of $\mathrm{BMCH}$, we assessed the mRNA expressions of p53, bax, bcl-2, and caspase-3 genes using RT-qPCR. As shown in Figure 6, $\mathrm{H}_{2} \mathrm{O}_{2}$ treatment alone significantly increased the mRNA expression of p53 and caspase-3, and the bax/bcl-2 ratio, reflecting the apoptotic state of cells [27]. The fold increase in p53, caspase-3, and the bax/bcl-2 ratio by $\mathrm{H}_{2} \mathrm{O}_{2}$ treatment alone was 1.07-, 2.48-, and 1.70-fold compared to that of the control group, respectively. However, these increases were decreased by $0.86-, 2.33-$, and 1.47-fold in p53, caspase-3, and the bax/bcl-2 ratio by $\mathrm{BMCH}$ treatment $(0.5 \mathrm{mg} / \mathrm{mL})$ compared to that of $\mathrm{H}_{2} \mathrm{O}_{2}$ treatment alone. But high concentration of $\mathrm{BMCH}$ did not reverse the gene expressions. Our results clearly showed that low concentration of BMCH is effective in $\mathrm{H}_{2} \mathrm{O}_{2}$-mediated $\mathrm{HUVEC}$ injury through downregulation of apoptotic p53 and caspase-3 genes, and the bax/bcl-2 ratio. 

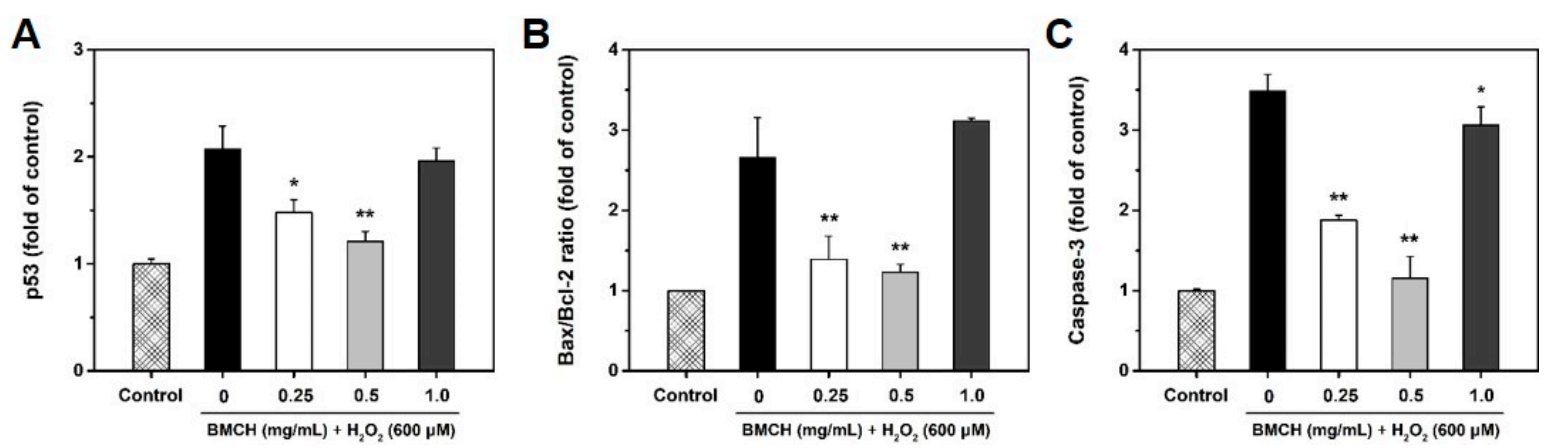

Figure 6. Effect of BMCH on mRNA expressions by RT-qPCR. (A) p53, (B) bax/bcl-2 ratio, and (C) caspase-3. Cells were pretreated with $\mathrm{BMCH}$ for $30 \mathrm{~min}$ followed by exposure of $\mathrm{H}_{2} \mathrm{O}_{2}(600 \mu \mathrm{M})$ and incubation for $24 \mathrm{~h} .{ }^{*} p<0.05$ and ${ }^{* *} p<0.01$ vs. $\mathrm{H}_{2} \mathrm{O}_{2}$ only treatment.

\subsection{Supression Caspase-3 Activation in $\mathrm{H}_{2} \mathrm{O}_{2}$-Induced HUVEC Injury}

Caspase- 3 is an important biomarker of apoptosis associated with ROS generation and activated by a cleavage when an apoptosis event occurs [28]. To investigate further information in correlation with the caspase- 3 activation pathway in $\mathrm{H}_{2} \mathrm{O}_{2}$-induced HUVEC apoptosis, caspase- 3 expression level was detected by western blotting. As shown in Figure 7, $\mathrm{H}_{2} \mathrm{O}_{2}$ treatment in HUVEC caused the cleavage of procaspase- 3 into the cleaved caspase-3, which triggered apoptosis in the cells; however, the cleaved caspase- 3 was decreased by $\mathrm{BMCH}$ treatment $(0.25$ and $0.5 \mathrm{mg} / \mathrm{mL})$ but not at high concentration $(1.0 \mathrm{mg} / \mathrm{mL})$. The result suggested that $\mathrm{BMCH}$ with low concentration supressed $\mathrm{H}_{2} \mathrm{O}_{2}$-induced apoptosis in HUVEC through the inactivation of caspase-3.

A

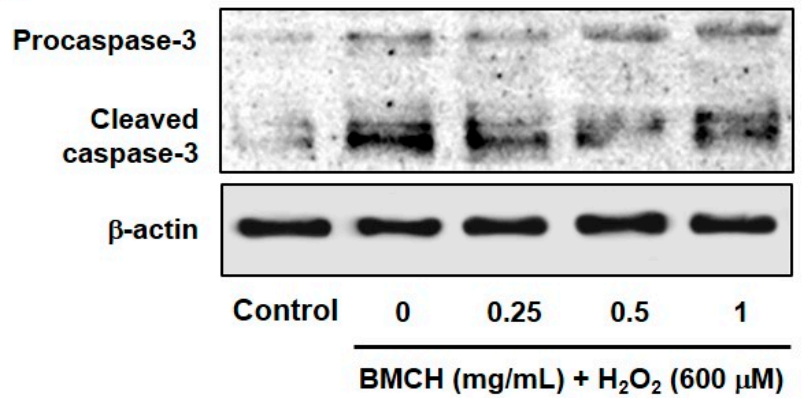

B

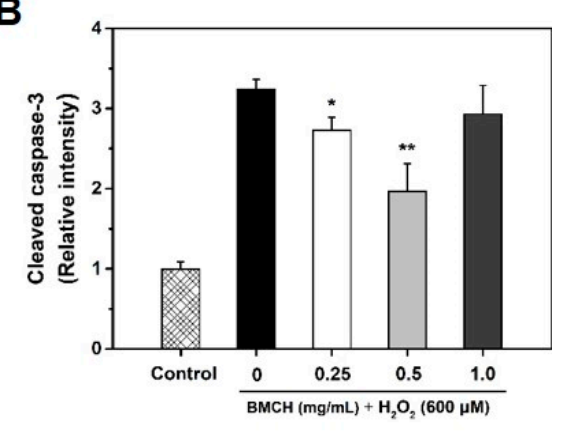

Figure 7. (A) Representative western blotting of procaspase- 3 and cleaved caspase-3, and (B) the relative expression level of cleaved caspase-3 protein level in $\mathrm{H}_{2} \mathrm{O}_{2}$-mediated HUVEC injury. Cells were pretreated with $\mathrm{BMCH}$ for $30 \mathrm{~min}$ followed by exposure of $\mathrm{H}_{2} \mathrm{O}_{2}(600 \mu \mathrm{M})$ and incubation for $24 \mathrm{~h}$. ${ }^{*} p<0.05$ and ${ }^{* *} p<0.01$ vs. $\mathrm{H}_{2} \mathrm{O}_{2}$ only treatment.

\subsection{Amino Acid Composition and Molecular Weight Distribution of BMCH}

BMCH enriched in Glu (9.32\%), Asp (7.67\%), and Gly (5.98\%) (Supplementary Table S1). Molecular weight of BMCH by Q-TOF mass spectrometer ranged from 323.24 to $1138.53 \mathrm{Da}$ (Supplementary Figure S1).

\section{Discussion}

Endothelial cells are directly involved in many functions of vascular biology, including barrier function, vascular homeostasis, inflammation, and formation and repair of blood vessels [29]. Endothelial damage and dysfunction are considered to be an early biomarker in the development of atherosclerosis and a hallmark for vascular diseases [30]. Because oxidative stress is considered to be a major cause in the pathogenesis of atherosclerosis, reduction of oxidative stress toward endothelial 
cells or LDL oxidation by oxidative stress is a good strategy for the prevention of the pathogenesis of atherosclerosis [31-33].

In this study, protein-rich blue mussel was hydrolyzed by eight enzymes to release bioactive peptides with antioxidant and anti-atherosclerotic activity. Antioxidant assays revealed that $\alpha$-chymotrypsin hydrolysates from blue mussel (BMCH) showed the best antioxidant activity determined by DPPH, $\mathrm{ABTS}^{+}$, and ORAC assays, and $\mathrm{BMCH}$ also inhibited $53 \%$ LDL oxidation mediated by $\mathrm{Cu}^{2+}$. Further, we chose $\mathrm{H}_{2} \mathrm{O}_{2}$-induced HUVEC injury as the model for investigation of anti-atherosclerotic effects and the underlying mechanism of $\mathrm{BMCH}$. In this study, $\mathrm{H}_{2} \mathrm{O}_{2}$ treatment resulted in the significant decrease of cell viability with the morphological features of apoptosis. However, BMCH $(0.25$ and $0.5 \mathrm{mg} / \mathrm{mL})$ treatment could reverse this injury to the normal condition as elevated cell viability, normalized morphology, and reduced apoptosis of HUVECs. These results showed that $\mathrm{BMCH}$ treatment may protect against $\mathrm{H}_{2} \mathrm{O}_{2}$-medicated oxidative damage in HUVECs.

ROS plays important roles in the regulation of various functions of cells. The endothelial homeostasis under normal condition can be balanced by the endogenous free radical production/antioxidant defense system, including intracellular antioxidant and antioxidant enzymes such as GSH, SOD, CAT, and GPx. However, overproduction of ROS leads to an imbalance in the oxidant/anti-oxidant mechanisms and subsequently results in oxidative endothelial damage [34,35]. GSH is the most abundant antioxidant in all cells, which can directly scavenge free radicals as an electron donor and act as a substrate for GPx and GST during the reduction of ROS [36]. In addition, SOD catalyzes superoxide radicals to oxygen or $\mathrm{H}_{2} \mathrm{O}_{2}$, followed by the decomposition of $\mathrm{H}_{2} \mathrm{O}_{2}$ through the catalytic reaction of GPx and CAT to water and oxygen. Thus, the activation of these antioxidant capacities is a good therapeutic strategy for the prevention of endothelial dysfunction by oxidative stress. To elucidate the underlying mechanisms of how $\mathrm{BMCH}$ treatment reverses this oxidative injury in endothelial cells, we determined cellular antioxidant levels, as well as ROS level in $\mathrm{H}_{2} \mathrm{O}_{2}$-induced HUVEC injury. It is well known that $\mathrm{H}_{2} \mathrm{O}_{2}$ treatment in vascular cells can stimulate ROS production, which are essential regulators of apoptosis, and reduces antioxidant defense capacity [25]. As expected, overproduction of ROS and depletion of antioxidant defense capacity were detected in $\mathrm{H}_{2} \mathrm{O}_{2}$-induced HUVEC injury. On the other hand, $\mathrm{BMCH}$ treatment prior to $\mathrm{H}_{2} \mathrm{O}_{2}$ exposure induced enhanced levels of endogenous antioxidant of GSH and antioxidant enzymes of SOD, CAT and GPx compared to that in $\mathrm{H}_{2} \mathrm{O}_{2}$-treated HUVEC alone. These results indicated that $\mathrm{BMCH}$ reduced oxidative stress through the elevating of cellular levels of antioxidant molecules.

In addition, oxidative damage induces nuclear damage and stimulates in association with the cascade of apoptotic cell death [37]. Apoptosis is characterized by morphological changes, such as cell shrinkage and chromatic condensation, and specific gene expression related to apoptotic signaling pathways such as p53, caspase-3, and bcl-2 family members [38,39]. p53 is strongly associated with the execution of apoptosis in response to oxidative stress-induced DNA damage [40,41]. In the intrinsic pathway, p53 activation results in an increase of bax and a decrease of bcl-2 expression that cause the release of cytochrome $C$ from the mitochondria. The released cytochrome $C$ activates downstream caspase-9, which subsequently activates caspase-3 that induces apoptosis [42,43]. Our studies clearly showed that $\mathrm{BMCH}$ treatment reversed the morphological changes and apoptotic process in $\mathrm{H}_{2} \mathrm{O}_{2}$-treated HUVEC injury. This effect is attributed to the downregulation of apoptotic gene expressions of p53 and caspase-3, and the bax/bcl-2 ratio. However, fold change in p53 and the bax/bcl-2 ratio by $\mathrm{BMCH}$ treatment is insufficient to elucidate the anti-apoptotic effect because of a less than 2-fold decrease of p53 gene expression compared to basal and / or $\mathrm{H}_{2} \mathrm{O}_{2}$ treatment alone groups [44]. Moreover, the bax/bcl-2 ratio is an important key factor in the regulation of apoptosis, and a low ratio of the bax/bcl-2 triggers cell death through activating caspase-3 [45]. Although the bax/bcl-2 ratio by $\mathrm{H}_{2} \mathrm{O}_{2}$ treatment alone is insufficiently increased (1.70-fold increase) compared to that of the control group, it could be speculating apoptotic cell death. However, the increased ratio was significantly decreased by $\mathrm{BMCH}$ treatment, suggesting that the $\mathrm{BMCH}$ treatment probably inhibited the apoptotic process by modulating the bax/bcl-2 ratio. Since the bax $/ \mathrm{bcl}-2$ ratio affects the activation 
of caspase-3, we further confirmed whether $\mathrm{BMCH}$ treatment inhibited caspase- 3 activation, which is a critical executioner of apoptosis [46]. As expected, the increased bax/bcl-2 ratio by $\mathrm{H}_{2} \mathrm{O}_{2}$ treatment alone up-regulated caspase-3 gene expression (2.48-fold increase), which is further confirmed by western blotting. However, our results clearly showed that $\mathrm{BMCH}$ treatment significantly decreased caspase- 3 activation in $\mathrm{H}_{2} \mathrm{O}_{2}$-treated HUVEC injury, and this decrease by $\mathrm{BMCH}$ treatment may be major protective pathway in our model. Taken together, $\mathrm{BMCH}$ treatment as antioxidants inhibits potent apoptotic cell death via enhancing intrinsic cellular tolerance against apoptotic stimuli; thus it can be further explored as potently anti-atherosclerosis.

\section{Materials and Methods}

\subsection{Materials}

Blue mussel (M. edulis) was purchased from Yeosu Fisheries Co. (Yeosu, Korea). Hydrogen peroxide $\left(\mathrm{H}_{2} \mathrm{O}_{2}\right)$, 2,2-diphenyl-1-picryhydrazyl (DPPH), potassium persulfate, 6-hydroxy-2,5,7,7-terramethyl chroman-2-carboxylic acid (Trolox), 2,2'-azino-bis-3-ehtylbenzthiazoline6-sulfonic acid (ABTS), trifluoroacetic acid (TFA), 2,2'-azobix-2-amidino-proparne dihydrochloride (AAPH), 2,5-diphenyltetrazolium bromide (MTT), monobromobimane (mBBr), 2'7'-dichlorofluorescin diacetate (DCFH-DA), and Hoechst 33342 were purchased from Sigma-Aldrich Chemical Co. (St. Louis, MO, USA). Chloroform, ethanol and dimethyl sulfoxide (DMSO) were purchased from Junsei Chemical Co. (Tokyo, Japan). Phosphate-Buffered Saline (PBS) and Dulbecco's PhosphateBuffered Saline (DPBS) were purchased from Hyclone (Logan, UT, USA). The complementary DNA synthesis kit (ET21025) and QuantiSpeed SYBR No-Rox kit (QS105-05) were obtained from PhileKorea (Seoul, Korea). All commercial chemicals were used without further purification.

\subsection{Preparation of Blue Mussel Hydrolysates}

Protein content in blue mussel M. edulis was determined by Kjeldahl method [47]. Blue mussel was thoroughly washed using tap water and lyophilized. Lyophilized blue mussel powder was

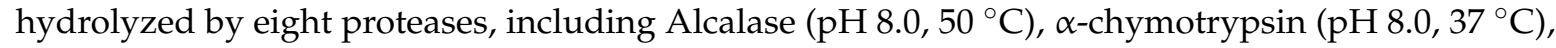
Flavourzyme $\left(\mathrm{pH} 7.0,50^{\circ} \mathrm{C}\right)$, Neutrase $\left(\mathrm{pH} 8.0,50^{\circ} \mathrm{C}\right)$, papain $\left(\mathrm{pH} 6.0,37^{\circ} \mathrm{C}\right)$, pepsin $\left(\mathrm{pH} 2.0,37^{\circ} \mathrm{C}\right)$, Protamex ( $\left.\mathrm{pH} 8.0,45^{\circ} \mathrm{C}\right)$, and trypsin $\left(\mathrm{pH} 8.0,37^{\circ} \mathrm{C}\right)$, at the enzyme to substrate ratio of 1:100 for $8 \mathrm{~h}$. After inactivation of the enzyme by boiling at $100^{\circ} \mathrm{C}$ for $10 \mathrm{~min}$, the hydrolysates were centrifuged at $5000 \mathrm{rpm}$ for $20 \mathrm{~min}$, and the supernatants were freeze-dried. The resultant blue mussel hydrolysates (BMHs) were stored at $-20^{\circ} \mathrm{C}$ until use.

\subsection{Determination of Antioxidant Activity}

\subsubsection{DPPH Radical Scavenging Assay}

DPPH radical scavenging activity of hydrolysates was performed as previously described in the methods of Park, Kim, Ahn and Je [19]. Briefly, a $70 \mu \mathrm{L}$ of BMHs was dissolved in a $70 \mu \mathrm{L}$ of $150 \mu \mathrm{M}$ DPPH, and then the mixtures were shaken vigorously for $10 \mathrm{~s}$ and kept for $30 \mathrm{~min}$ in the dark. The absorbance was measured at $517 \mathrm{~nm}$ using a microplate reader after $30 \mathrm{~min}$. The DPPH radical scavenging activity was expressed as $\mathrm{IC}_{50}$ value, which is the concentration required to scavenge $50 \%$ of the DPPH radical.

\subsection{2. $\mathrm{ABTS}^{+}$Radical Scavenging Assay}

$\mathrm{ABTS}^{+}$radical scavenging activity was determined by the method of Park and Kim [48]. The stock solution was prepared by mixing with a $7.4 \mathrm{mM} \mathrm{ABTS}^{+}$solution and a $2.6 \mathrm{mM}$ potassium persulfate at a ratio of 1:1. The stock solution was diluted to the working solution with an absorbance of $1.50 \pm 0.05$ at $414 \mathrm{~nm}$. A $50 \mu \mathrm{L}$ of BMHs was added in $150 \mu \mathrm{L}$ of the working solution and incubated for $10 \mathrm{~min}$ 
at room temperature. The absorbance was measured at $414 \mathrm{~nm}$. $\mathrm{ABTS}^{+}$radical scavenging activities were expressed as $\mu \mathrm{M}$ trolox equivalents (TE)/mg hydrolysates.

\subsubsection{ORAC Assay}

ORAC value was determined according to the method of Zulueta, et al. [49] with slight modifications. Briefly, a $50 \mu \mathrm{L}$ of BMHs in sodium phosphate buffer $(75 \mathrm{mM}, \mathrm{pH} 7.0)$ was mixed with $50 \mu \mathrm{L}$ of fluorescein $(78 \mathrm{nM})$ in a 96-well microplate and incubated at $37{ }^{\circ} \mathrm{C}$ for $15 \mathrm{~min}$. After addition of $25 \mu \mathrm{L}$ of AAPH $(221 \mathrm{mM})$, fluorescence was measured every $5 \mathrm{~min}$ for $60 \mathrm{~min}(\mathrm{Ex} / \mathrm{Em}=485 \mathrm{~nm} / 582 \mathrm{~nm})$. ORAC values were expressed as $\mu \mathrm{M}$ Trolox equivalents (TE)/mg hydrolysates.

\subsection{LDL Oxidation Inhibitory Activity}

Inhibitory effect of BMCH on human LDL oxidation by $\mathrm{Cu}^{2+}$ was measured by thiobarbituric acid reactive substances (TBARS) assay. Briefly, a $100 \mu \mathrm{g} / \mathrm{mL}$ of human LDL (Lee BioSolutions, Missouri, $\mathrm{MO}$, USA) was oxidized with $10 \mu \mathrm{M} \mathrm{Cu}^{2+}$ at $37^{\circ} \mathrm{C}$ for $18 \mathrm{~h}$ in the presence or absence of BMCH. After incubation, a $30 \mu \mathrm{L}$ of EDTA $(1 \mathrm{mM})$ was added to terminate reaction, followed by adding $200 \mu \mathrm{L}$ of TCA $(20 \% w / v)$ and TBA $(1 \% w / v$ in $0.3 \% \mathrm{NaOH})$. The mixture was then heated at $92{ }^{\circ} \mathrm{C}$ for $20 \mathrm{~min}$. The mixture was centrifuged at $4000 \mathrm{rpm}$ for $15 \mathrm{~min}$ (LZ-1248R, Labogene, Seoul, Korea), and the absorbance of the supernatant was measured at $532 \mathrm{~nm}$. Lipid peroxidation in oxidized-LDL was expressed as $\mu \mathrm{M}$ MDA referring to MDA standard calibration curve.

\subsection{Cell Culture and Treatments}

HUVECs were purchased from the American Type Culture Collection (ATCC; Rockville, MD, USA). The cells were cultured in vascular basal cell medium (ATCC) containing $2 \%$ fetal bovine serum (FBS; ATCC), $100 \mathrm{U} / \mathrm{mL}$ of penicillin/streptomycin (Hyclone, Logan, UT, USA), and supplemented with endothelial cell growth kit-VEGF (ATCC). The cells were maintained at $37^{\circ} \mathrm{C}$ in a humidified incubator with $5 \% \mathrm{CO}_{2}$, and cell growth medium was changed every two days. The cells were subcultured using a $0.025 \%$ trypsin-EDTA solution. The cells used in this study were designated as passage 3 to 5 .

To investigate the protective effect of BMCH against oxidative stress, HUVECs were seeded in a 96-well or 6-well plate or $100 \mathrm{~mm}^{2}$ dishes and maintained in a $5 \% \mathrm{CO}_{2}$ incubator. When HUVECs reached $80-90 \%$ confluence, the HUVECs were pretreated with BMCH $(0,0.25,0.5$ and $1 \mathrm{mg} / \mathrm{mL})$ for $30 \mathrm{~min}$ and then exposed to $600 \mu \mathrm{M} \mathrm{H}_{2} \mathrm{O}_{2}$ for $24 \mathrm{~h}$. The control group was not treated with $\mathrm{BMCH}$ and $\mathrm{H}_{2} \mathrm{O}_{2}$.

\subsection{Determination of Cytoprotective Effect in $\mathrm{H}_{2} \mathrm{O}_{2}$-Mediated HUVEC Injury}

\subsubsection{Cell Viability Assay}

Cell viability was evaluated by using MTT assay. After treatment with $\mathrm{BMCH}$ and $\mathrm{H}_{2} \mathrm{O}_{2}$ in a 96-well plate described above, the MTT solution $(0.5 \mathrm{mg} / \mathrm{mL})$ was added to each well and further incubated for $4 \mathrm{~h}$. After removing MTT and adding $100 \mu \mathrm{L}$ of DMSO, the absorbance of intracellular purple formazan crystals was measured at a wavelength of $540 \mathrm{~nm}$ using a GENios microplate reader (GENios, TECAN, Männedorf, Switzerland).

\subsubsection{Live/Dead Cell Assay}

The live/dead cell assay was utilized for fluorescence staining of viable and dead cells. The cells were simultaneously dual-stained with calcein-AM and PI, which produce green fluorescence in live cells and red fluorescence in dead cells, respectively. After treatment with $\mathrm{BMCH}$ and $\mathrm{H}_{2} \mathrm{O}_{2}$ in a 12-well black plate for $24 \mathrm{~h}$, the cells were incubated with $0.5 \mu \mathrm{M}$ calcein-AM and $5 \mu \mathrm{M}$ PI dye solution at $37^{\circ} \mathrm{C}$ for $20 \mathrm{~min}$ while protected from light. After washing PBS, viable and dead cells 
labeled with calcein-AM and PI were visualized under a fluorescence microscope (Leica DMI 6000 B, Wetzlar, Germany).

\subsubsection{Measurement of Intracellular Glutathione (GSH) Levels}

GSH levels were evaluated by monobromobimane $(\mathrm{mBBr})$ as a fluorescent thiol probe [50]. After treatment with $\mathrm{BMCH}$ and $\mathrm{H}_{2} \mathrm{O}_{2}$ in a 96-well black plate described above, the cells were treated with $40 \mu \mathrm{M}$ of $\mathrm{mBBr}$ for $30 \mathrm{~min}$ to form a fluorescent of $\mathrm{mBBr}-\mathrm{GSH}$ conjugate, followed by detecting fluorescence at the wavelength of Ex/Em $360 \mathrm{~nm} / 465 \mathrm{~nm}$ using a GENios microplate reader.

\subsubsection{Intracellular ROS Measurement}

Intracellular ROS generation was measured using a DCFH-DA in $\mathrm{H}_{2} \mathrm{O}_{2}$-treated HUVECs. After treatment with $\mathrm{BMCH}$ and $\mathrm{H}_{2} \mathrm{O}_{2}$ in a 96-well black plate as described above, the cells were incubated with $20 \mu \mathrm{M}$ DCFH-DA (final Con.) in PBS for $20 \mathrm{~min}$ at $37^{\circ} \mathrm{C}$. After washing with PBS, intracellular ROS generation was monitored using fluorescence microscopy, and the DCF fluorescence intensity was quantified at the wavelength of Ex/Em $485 \mathrm{~nm} / 535 \mathrm{~nm}$ using a GENios microplate reader.

\subsubsection{Determination of Antioxidant Enzyme Activities}

After treatment with $\mathrm{BMCH}$ and $\mathrm{H}_{2} \mathrm{O}_{2}$ in $100 \mathrm{~mm}^{2}$ dishes described above, the cell lysates were prepared using RIPA buffer (Sigma, St. Louis, MO, USA). Cellular antioxidant enzyme activities, including SOD, CAT, and GPx, were determined by using enzyme assay kits (Cayman, Ann Arbor, MI, USA) according to the manufacturer's instructions.

\subsubsection{Cellular Morphological Changes}

Hoechst 33342 nuclear staining was conducted to detect apoptotic changes. After treatment with $\mathrm{BMCH}$ and $\mathrm{H}_{2} \mathrm{O}_{2}$ in a 6-well plate described above, the cells were fixed with an ice-cold ethanol (75\%) for $20 \mathrm{~min}$, followed by staining with $10 \mu \mathrm{M}$ Hoechst 33342 for $20 \mathrm{~min}$ at room temperature. The cells were washed with PBS and the morphology was observed using a fluorescence microscope (Leica DMI $6000 \mathrm{~B})$.

\subsubsection{Cell Apoptosis and Necrosis Analysis by Flow Cytometry}

Cell apoptosis and necrosis were determined by using an Annexin V-FITC Apoptosis Detection Kit (BD Pharmingen ${ }^{\mathrm{TM}}$, San Jose, CA, USA) according to the manufacturer's protocol. After treatment with $\mathrm{BMCH}$ and $\mathrm{H}_{2} \mathrm{O}_{2}$ in HUVECs described above, the cells were harvested and collected at a density of $5 \times 10^{5}$ cells by centrifugation, followed by resuspension in $100 \mu \mathrm{L}$ of $1 \times$ binding buffer. The cells were incubated with $10 \mu \mathrm{g} / \mathrm{mL}$ of Annexin V-FITC/PI double staining solution for $15 \mathrm{~min}$ at room temperature in the dark, followed by the addition of $400 \mu \mathrm{L}$ of $1 \times$ binding buffer. The fluorescence was immediately analyzed with flow cytometry (FACSCalibur system, BD Biosciences, San Jose, CA, USA).

\subsection{8. mRNA Expression by Real Time-qPCR}

Total RNA was isolated using TRIzol reagent (Thermo scientific Co., Waltham, MA, USA). The isolated RNA was converted into cDNA using cDNA synthesis kit (ET21025, PhileKorea, Seoul, Korea). Human p53, caspase-3, bcl-2, and bax transcripts were quantified by RT-qPCR using QuantiSpeed SYBR No-Rox kit (QS105-05, PhileKorea, Seoul, Korea). The PCR reaction was carried out at $95^{\circ} \mathrm{C}$ for $2 \mathrm{~min}$ to activation of polymerase, followed by 40 cycles of denaturation at $95^{\circ} \mathrm{C}$ for $5 \mathrm{~s}$, and annealing/extension at $60^{\circ} \mathrm{C}$ for $20 \mathrm{~s}$. Melting temperature was set from $50{ }^{\circ} \mathrm{C}$ to $95^{\circ} \mathrm{C}$ at $0.3^{\circ} \mathrm{C} / \mathrm{s}$. Primers used in this study are listed as follows: $\beta$-actin (forward: CTG TCT GGC GGC ACC ACC AT, reverse: GCA ACT AAG TCA TAG TCC GC), bax (forward: TCT GAC GGC AAC TTC AAC TG, reverse: CTC AGC CCA TCT TCT TCC AG), bcl-2 (forward: AGA TGT CCA CFF AGC TGC 
ACC TGA C, reverse: AGA TAG GCA CCC AGG GTG ATG CAA GCT), caspase-3 (forward: ATT GTG GAA TTG ATG CGT GA, reverse: GGC AGG CCT GAA TAA TGA AA), and p53 (forward: GTT CCG AGA GCT GAA TGA GG, reverse: CTG AGT CAG GCC CTT CTG TC). The $\beta$-actin was used a housekeeping gene and all results are normalized to the level of $\beta$-actin expression. Relative fold change values were calculated following formula [51]:

$$
\text { Relative mRNA expression }=2^{-(\Delta \mathrm{C}, \mathrm{BMCH}-\Delta \mathrm{C} \text {,blank })}
$$

where, $\Delta C_{x}=C_{x}$ interest gene $-C_{x}$ housekeeping gene, $\mathrm{x}$ is blank or $\mathrm{BMCH}$.

\subsubsection{Western Blotting}

After treatment with $\mathrm{BMCH}$ and $\mathrm{H}_{2} \mathrm{O}_{2}$ for $24 \mathrm{~h}$, protein was isolated using a RIPA buffer (Sigma Chemical Co. St. Louis, MO, USA) and quantified using a Pierce ${ }^{\circledR}$ BCA protein assay kit (Thermo Scientific Co., Waltham, MA, USA). Equal amounts of proteins were loaded and separated by $10 \%$ SDS-PAGE gel through gel electrophoresis, and then the proteins were transferred to a PVDF membrane. After blocking with TBS-T buffer containing 5\% skim milk, the membrane was incubated with caspase-3 (Cat. No. sc-271759) and $\beta$-actin (Cat. No. sc-47778) primary antibodies overnight at $4{ }^{\circ} \mathrm{C}$. After washing with TBS-T, the membrane was further incubated with horseradish peroxidase-conjugated secondary antibody for $2 \mathrm{~h}$. The protein band was imaged on Davinch-Chemi ${ }^{\mathrm{TM}}$ imaging system (Core Bio, Seoul, Korea) and the relative intensity of activated caspase-3 protein expression was calculated using imageJ software (version 1.52a, NIH, Bethesda, MD, USA), compared to the $\beta$-actin band.

\subsection{Characterization of Blue Mussel Hydrolysates}

The amino acid composition was analyzed by an amino acid autoanalyzer (S43000, Sykam Eresing, Germany) using a cation separation column (LCA K06/Na, $4.6 \times 150 \mathrm{~mm}$ ). Molecular weight distribution was determined using Ultra High Resolution Q-TOF Mass Spectrometer (Bruker Daltonics, Leipzig, Germany).

\subsection{Statistical Analysis}

Data are presented as means $\pm \mathrm{SD}$. Student's t-test was used to determine any statistical significance, and the experiments for each sample were repeated at least three times. Differences were considered statistical significant at ${ }^{*} p<0.05$ and ${ }^{* *} p<0.01$ compared with the cells treated with $\mathrm{H}_{2} \mathrm{O}_{2}$ only.

\section{Conclusions}

In this study, we demonstrated the anti-atherosclerotic effect of blue mussel hydrolysates by $\alpha$-chymotrypsin $(\mathrm{BMCH})$. The antioxidant effect by $\mathrm{BMCH}$ was attributed to the promotion of intracellular antioxidant defense capacity, such as GSH, SOD, CAT, and GPx, and the inhibition of apoptotic pathway such as downregulation of apoptotic gene expressions of p53, caspase-3, and the bax and upregulation of bcl-2 in $\mathrm{H}_{2} \mathrm{O}_{2}$-induced HUVEC injury. Finally, $\mathrm{BMCH}$ treatment represented excellent antioxidant effects leading to the suppression of endothelial cell apoptosis through the casase-3 activation pathway against $\mathrm{H}_{2} \mathrm{O}_{2}$-induced HUVEC injury. Our findings provide new insight of the potential use of marine proteins or hydrolysates as functional food ingredients for protecting endothelial dysfunction.

Supplementary Materials: The following are available online at http:/ / www.mdpi.com/1660-3397/17/2/135/s1, Figure S1: Molecular weight distribution of BMCH, Table S1: Total amino acid composition of BMCH (g/100 g).

Author Contributions: Formal analysis, data curation, and writing—original draft preparation, Y.O. \& C.-B.A.; sample preparation, K.-H.N., Y.-K.K., N.Y.Y.; supervision, J.-Y.J. 
Funding: This study was supported by a grant from the National Institute of Fisheries Science in Korea (R2019053).

Conflicts of Interest: The authors declare that there are no conflicts of interest.

\section{References}

1. Benjamin, E.J.; Blaha, M.J.; Chiuve, S.E.; Cushman, M.; Das, S.R.; Deo, R.; Floyd, J.; Fornage, M.; Gillespie, C.; Isasi, C. Heart disease and stroke statistics-2017 update: A report from the American Heart Association. Circulation 2017, 135, e146-e603. [CrossRef] [PubMed]

2. Esper, R.J.; Nordaby, R.A.; Vilariño, J.O.; Paragano, A.; Cacharrón, J.L.; Machado, R.A. Endothelial dysfunction: A comprehensive appraisal. Cardiovasc. Diabetol. 2006, 5, 1-18. [CrossRef] [PubMed]

3. Mudau, M.; Genis, A.; Lochner, A.; Strijdom, H. Endothelial dysfunction: The early predictor of atherosclerosis. Cardiovasc. J. Afr. 2012, 23, 222-231. [CrossRef] [PubMed]

4. Thanassoulis, G.; Campbell, C.Y.; Owens, D.S.; Smith, J.G.; Smith, A.V.; Peloso, G.M.; Kerr, K.F.; Pechlivanis, S.; Budoff, M.J.; Harris, T.B. Genetic associations with valvular calcification and aortic stenosis. N. Engl. J. Med. 2013, 368, 503-512. [CrossRef] [PubMed]

5. Singh, R.B.; Mengi, S.A.; Xu, Y.-J.; Arneja, A.S.; Dhalla, N.S. Pathogenesis of atherosclerosis: A multifactorial process. Exp. Clin. Cardiol. 2002, 7, 40-53. [PubMed]

6. Cai, H.; Harrison, D.G. Endothelial dysfunction in cardiovascular diseases: The role of oxidant stress. Circ. Res. 2000, 87, 840-844. [CrossRef] [PubMed]

7. Bonetti, P.O.; Lerman, L.O.; Lerman, A. Endothelial dysfunction: A marker of atherosclerotic risk. Arterioscler. Thromb. Vasc. Biol. 2003, 23, 168-175. [CrossRef] [PubMed]

8. Davi, G.; Falco, A. Oxidant stress, inflammation and atherogenesis. Lupus 2005, 14, 760-764. [CrossRef] [PubMed]

9. Foncea, R.; Carvajal, C.; Almarza, C.; Leighton, F. Endothelial cell oxidative stress and signal transduction. Biol. Res. 2000, 33, 86-96. [CrossRef]

10. Taylor, W.C.; Landau, W.M. Atherosclerosis and stroke. Ann. Neurol. 1990, 28, 108. [CrossRef] [PubMed]

11. Falk, E. Pathogenesis of atherosclerosis. J. Am. Coll. Cardiol. 2006, 47 (Suupl. 8), C7-C12. [CrossRef] [PubMed]

12. Ngo, D.-H.; Kim, S.-K. Marine bioactive peptides as potential antioxidants. Curr. Protein Pept. Sci. 2013, 14, 189-198. [CrossRef] [PubMed]

13. Takamatsu, S.; Hodges, T.W.; Rajbhandari, I.; Gerwick, W.H.; Hamann, M.T.; Nagle, D.G. Marine natural products as novel antioxidant prototypes. J. Nat. Prod. 2003, 66, 605-608. [CrossRef] [PubMed]

14. Wu, R.; Wu, C.; Liu, D.; Yang, X.; Huang, J.; Zhang, J.; Liao, B.; He, H.; Li, H. Overview of antioxidant peptides derived from marine resources: The sources, characteristic, purification, and evaluation methods. Appl. Biochem. Biotechnol. 2015, 176, 1815-1833. [CrossRef] [PubMed]

15. Je, J.-Y.; Cha, J.-Y.; Cho, Y.-S.; Ahn, H.-Y.; Lee, J.H.; Cho, Y.-S.; Ahn, C.-B. Hepatoprotective effect of peptic hydrolysate from salmon pectoral fin protein byproducts on ethanol-induced oxidative stress in Sprague-Dawley rats. Food Res. Int. 2013, 51, 648-653. [CrossRef]

16. Hyung, J.-H.; Ahn, C.-B.; Je, J.-Y. Blue mussel (Mytilus edulis) protein hydrolysate promotes mouse mesenchymal stem cell differentiation into osteoblasts through up-regulation of bone morphogenetic protein. Food Chem. 2018, 242, 156-161. [CrossRef] [PubMed]

17. Sarmadi, B.H.; Ismail, A. Antioxidative peptides from food proteins: A review. Peptides 2010, 31, $1949-1956$. [CrossRef] [PubMed]

18. Wang, B.; Li, L.; Chi, C.F.; Ma, J.H.; Luo, H.Y.; Xu, Y.F. Purification and characterisation of a novel antioxidant peptide derived from blue mussel (Mytilus edulis) protein hydrolysate. Food Chem. 2013, 138, 1713-1719. [CrossRef] [PubMed]

19. Park, S.Y.; Kim, Y.-S.; Ahn, C.-B.; Je, J.-Y. Partial purification and identification of three antioxidant peptides with hepatoprotective effects from blue mussel (Mytilus edulis) hydrolysate by peptic hydrolysis. J. Funct. Foods 2016, 20, 88-95. [CrossRef]

20. Chen, W.-L.; Qian, Y.; Meng, W.-F.; Pang, J.-Y.; Lin, Y.-C.; Guan, Y.-Y.; Chen, S.-P.; Liu, J.; Pei, Z.; Wang, G.-L. A novel marine compound xyloketal B protects against oxidized LDL-induced cell injury in vitro. Biochem. Pharmacol. 2009, 78, 941-950. [CrossRef] [PubMed] 
21. Liu, S.; Luo, R.; Xiang, Q.; Xu, X.; Qiu, L.; Pang, J. Design and synthesis of novel xyloketal derivatives and their protective activities against $\mathrm{H}_{2} \mathrm{O}_{2}$-induced HUVEC injury. Mar. Drugs 2015, 13, 948-973. [CrossRef] [PubMed]

22. Kang, M.-C.; Lee, S.-H.; Lee, W.-W.; Kang, N.; Kim, E.-A.; Kim, S.Y.; Lee, D.H.; Kim, D.; Jeon, Y.-J. Protective effect of fucoxanthin isolated from Ishige okamurae against high-glucose induced oxidative stress in human umbilical vein endothelial cells and zebrafish model. J. Funct. Foods 2014, 11, 304-312. [CrossRef]

23. Higashi, Y.; Maruhashi, T.; Noma, K.; Kihara, Y. Oxidative stress and endothelial dysfunction: Clinical evidence and therapeutic implications. Trends Cardiovasc. Med. 2014, 24, 165-169. [CrossRef] [PubMed]

24. Leiva, E.; Wehinger, S.; Guzmán, L.; Orrego, R. Role of Oxidized LDL in Atherosclerosis. In Hypercholesterolemia; InTech: London, UK, 2015.

25. Liang, Y.; Lin, Q.; Huang, P.; Wang, Y.; Li, J.; Zhang, L.; Cao, J. Rice Bioactive Peptide Binding with TLR4 To Overcome $\mathrm{H}_{2} \mathrm{O}_{2}$-Induced Injury in Human Umbilical Vein Endothelial Cells through NF- $\mathrm{kB}$ Signaling. J. Agric. Food Chem. 2018, 66, 440-448. [CrossRef] [PubMed]

26. Kerksick, C.; Willoughby, D. The antioxidant role of glutathione and N-acetyl-cysteine supplements and exercise-induced oxidative stress. J. Int. Soc. Sports Nutr. 2005, 2, 38-44. [CrossRef] [PubMed]

27. Faucher, K.; Rabinovitch-Chable, H.; Cook-Moreau, J.; Barrière, G.; Sturtz, F.; Rigaud, M. Overexpression of human GPX1 modifies Bax to Bcl-2 apoptotic ratio in human endothelial cells. Mol. Cell. Biochem. 2005, 277, 81-87. [CrossRef] [PubMed]

28. Chen, Y.C.; Lin-Shiau, S.Y.; Lin, J.K. Involvement of reactive oxygen species and caspase 3 activation in arsenite-induced apoptosis. J. Cell. Physiol. 1998, 177, 324-333. [CrossRef]

29. Michiels, C. Endothelial cell functions. J. Cell. Physiol. 2003, 196, 430-443. [CrossRef] [PubMed]

30. Lin, X.-L.; Liu, Y.; Liu, M.; Hu, H.; Pan, Y.; Fan, X.-J.; Hu, X.-M.; Zou, W.-W. Inhibition of hydrogen peroxide-induced human umbilical vein endothelial cells aging by allicin depends on Sirtuin1 activation. Med. Sci. Monit. 2017, 23, 563-570. [CrossRef] [PubMed]

31. Nowak, W.N.; Deng, J.; Ruan, X.Z.; Xu, Q. Reactive oxygen species generation and atherosclerosis. Arterioscler. Thromb. Vasc. Biol. 2017, 37, e41-e52. [CrossRef] [PubMed]

32. Singh, U.; Jialal, I. Oxidative stress and atherosclerosis. Pathophysiology 2006, 13, 129-142. [CrossRef] [PubMed]

33. Harrison, D.; Griendling, K.K.; Landmesser, U.; Hornig, B.; Drexler, H. Role of oxidative stress in atherosclerosis. Am. J. Cardiol. 2003, 91, 7-11. [CrossRef]

34. Förstermann, U. Oxidative stress in vascular disease: Causes, defense mechanisms and potential therapies. Nat. Rev. Cardiol. 2008, 5, 338-349. [CrossRef] [PubMed]

35. Victor, V.M.; Rocha, M.; Sola, E.; Banuls, C.; Garcia-Malpartida, K.; Hernandez-Mijares, A. Oxidative stress, endothelial dysfunction and atherosclerosis. Curr. Pharm. Des. 2009, 15, 2988-3002. [CrossRef] [PubMed]

36. Petrulea, M.; Muresan, A.; Duncea, I. Oxidative stress and antioxidant status in hypo-and hyperthyroidism. In Antioxidant Enzyme; InTech: London, UK, 2012.

37. Choi, Y.-J.; Kang, J.-S.; Park, J.H.Y.; Lee, Y.-J.; Choi, J.-S.; Kang, Y.-H. Polyphenolic flavonoids differ in their antiapoptotic efficacy in hydrogen peroxide-treated human vascular endothelial cells. J. Nutr. 2003, 133, 985-991. [CrossRef] [PubMed]

38. Ziegler, U.; Groscurth, P. Morphological features of cell death. Physiology 2004, 19, 124-128. [CrossRef]

39. Redza-Dutordoir, M.; Averill-Bates, D.A. Activation of apoptosis signalling pathways by reactive oxygen species. Biochim. Biophys. Acta (BBA) Mol. Cell Res. 2016, 1863, 2977-2992. [CrossRef] [PubMed]

40. Polyak, K.; Xia, Y.; Zweier, J.L.; Kinzler, K.W.; Vogelstein, B. A model for p53-induced apoptosis. Nature 1997, 389, 300-305. [CrossRef] [PubMed]

41. Wang, G.W.; Lv, C.; Shi, Z.R.; Zeng, R.T.; Dong, X.Y.; Zhang, W.D.; Liu, R.H.; Shan, L.; Shen, Y.H. Abieslactone induces cell cycle arrest and apoptosis in human hepatocellular carcinomas through the mitochondrial pathway and the generation of reactive oxygen species. PLoS ONE 2014, 9, 1-19. [CrossRef] [PubMed]

42. Lotem, J.; Peled-Kamar, M.; Groner, Y.; Sachs, L. Cellular oxidative stress and the control of apoptosis by wild-type p53, cytotoxic compounds, and cytokines. Proc. Natl. Acad. Sci. USA 1996, 93, 9166-9171. [CrossRef] [PubMed]

43. Valen, G. The basic biology of apoptosis and its implications for cardiac function and viability. Ann. Thorac. Surg. 2003, 75, S656-S660. [CrossRef] 
44. Kuang, J.; Yan, X.; Genders, A.J.; Granata, C.; Bishop, D.J. An overview of technical considerations when using quantitative real-time PCR analysis of gene expression in human exercise research. PLOS ONE 2018, 13, e0196438. [CrossRef] [PubMed]

45. Oh, Y.; Ahn, C.B.; Yoon, N.Y.; Nam, K.H.; Kim, Y.K.; Je, J.Y. Protective effect of enzymatic hydrolysates from seahorse (Hippocampus abdominalis) against $\mathrm{H}_{2} \mathrm{O}_{2}$-mediated human umbilical vein endothelial cell injury. Biomed. Pharmacother. 2018, 108, 103-110. [CrossRef] [PubMed]

46. Porter, A.G.; Jänicke, R.U. Emerging roles of caspase-3 in apoptosis. Cell Death Differ. 1999, 6, 99-104. [CrossRef] [PubMed]

47. Ismail, N.A.; Okasha, S.H.; Dhawan, A.; Abdel-Rahman, A.O.; Shaker, O.G.; Sadik, N.A. Antioxidant enzyme activities in hepatic tissue from children with chronic cholestatic liver disease. Saudi J. Gastroenterol. 2010, 16, 90-94. [CrossRef] [PubMed]

48. Park, P.J.; Kim, C.H. Extraction of polyphenols from apple peel using cellulase and pectinase and estimation of antioxidant activity. J. Korean Soc. Food Sci. Nutr. 2009, 38, 535-540. [CrossRef]

49. Zulueta, A.; Esteve, M.J.; Frígola, A. ORAC and TEAC assays comparison to measure the antioxidant capacity of food products. Food Chem. 2009, 114, 310-316. [CrossRef]

50. Poot, M.; Verkerk, A.; Koster, J.F.; Jongkind, J.F. De novo synthesis of glutathione in human fibroblasts during in vitro ageing and in some metabolic diseases as measured by a flow cytometric method. Biochim. Biophys. Acta (BBA) Gen. Subj. 1986, 883, 580-584. [CrossRef]

51. Schmittgen, T.D.; Livak, K.J. Analyzing real-time PCR data by the comparative C T method. Nat. Protoc. 2008, 3, 1101-1108. [CrossRef] [PubMed]

(C) 2019 by the authors. Licensee MDPI, Basel, Switzerland. This article is an open access article distributed under the terms and conditions of the Creative Commons Attribution (CC BY) license (http:/ / creativecommons.org/licenses/by/4.0/). 